
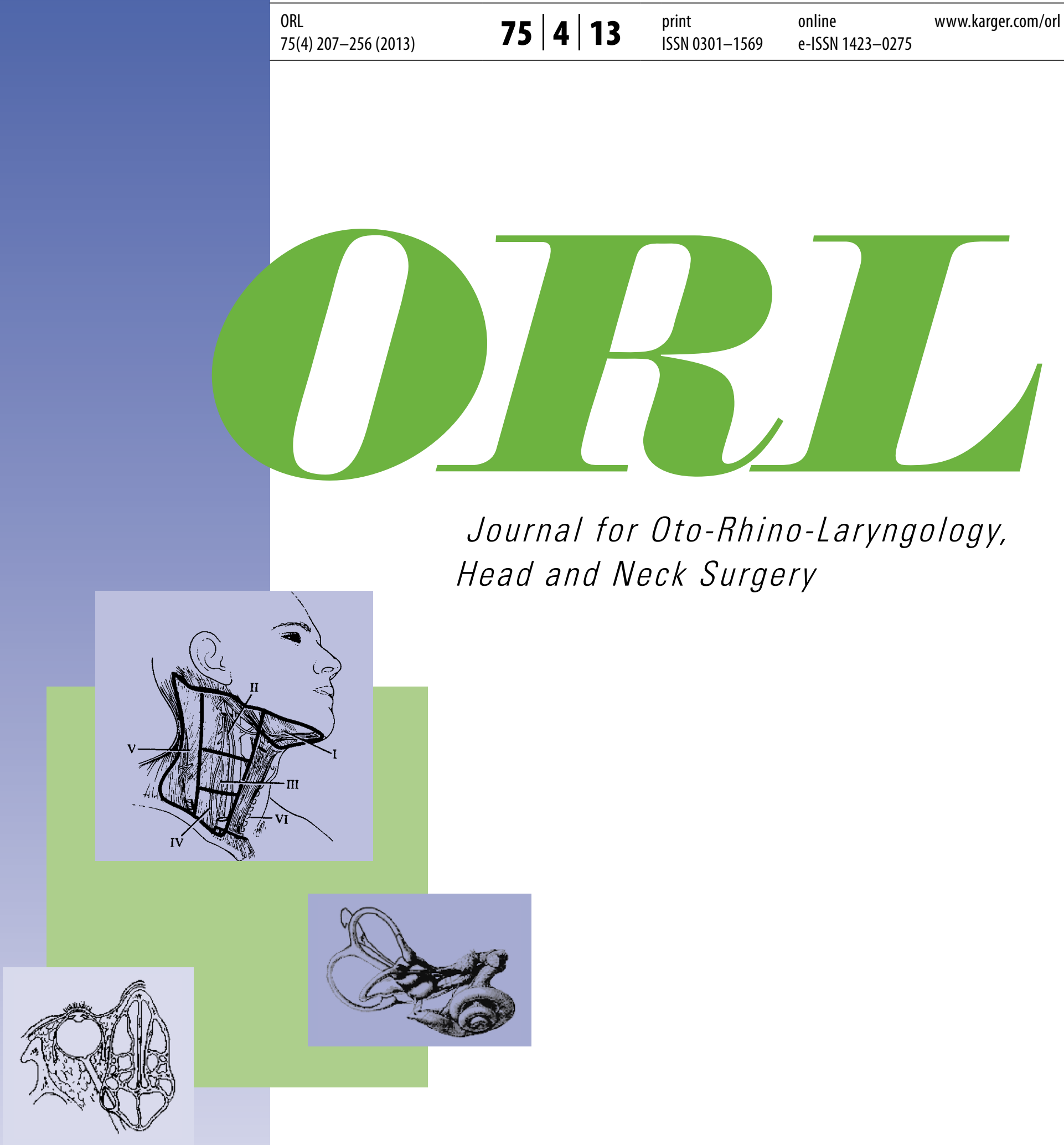

S. Karger

Medical and Scientific Publishers $\mathrm{KA} R \mathrm{R}$ Basel · Freiburg · Paris . London - New York ·

New Delhi · Bangkok · Beijing · Tokyo · Kuala Lumpur .

Singapore $\cdot$ Sydney 


\title{
Garger
}

\section{Stimulating reading} in and around the world of medicine

The biomedical themes of the Karger Gazette are topical, urgent, exciting. Its articles, written by experts from all over the world, provide a wide audience with the basic issues, new findings and controversies in a lively and readable style. Alongside invited contributions, each number carries attractively presented support material, such as informative graphics, historical summaries, interviews, or portraits of individuals and institutions. The Karger Gazette is published in newspaper format and appears once a year.

And what's more - it's free!

To see behind the cover, please write or e-mail us, and we'll start your subscription with the latest issue. www.karger.com/gazette

Current issue:

\section{The Aging Issue}

Read about the causes of the aging process, why aging stops in later adult life, the quiet epidemic of Alzheimer's Disease, internet use by seniors, and more.

\author{
S. Karger AG \\ Karger Gazette \\ Allschwilerstrasse 10 \\ CH-4009 Basel (Switzerland) \\ E-Mail gazette@karger.com \\ www.karger.com
}

\section{KARGER}




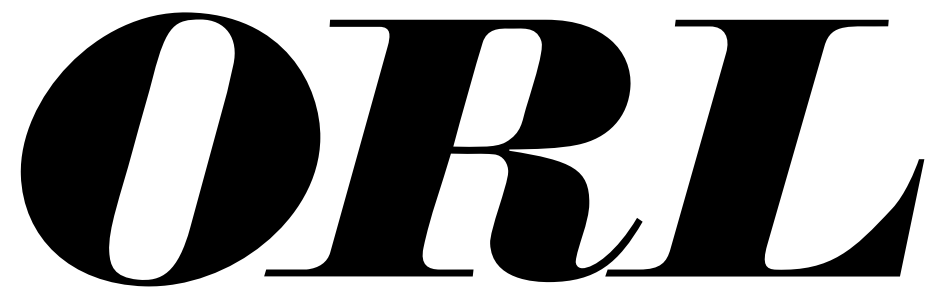

\section{Journal for Oto-Rhino-Laryngology, Head and Neck Sugery}

Founded 1938 as 'Practica Oto-Rhino-Laryngologica' by J. Berberich and E. Schlittler, continued by L. Rüedi 1947-1970, E. Huizinga 1948-1970, C.R. Pfaltz 1968-1984,

W. Arnold 1985-2002

Incorporating 'Oto-Rhino-Laryngologia Nova'

\section{Editor-in-Chief}

Bert W. O’Malley, Jr.,

Philadelphia, Pa. (USA)

Bert.OMalley@uphs.upenn.edu

\section{Co-Editor}

Daqing Li,

Philadelphia, Pa. (USA)

\section{Associate Editors}

Wolfgang Arnold, Kastanienbaum (Switzerland)

Fernando L. Dias, Rio de Janeiro (Brasil)

Hinrich Staecker, Kansas City, Kans. (USA)

Tatsuya Yamasoba, Tokyo (Japan)

\section{Controversial Issues Editor}

Jean-Philippe Guyot, Genève (Switzerland)

Basile N. Landis, Genève (Switzerland)

\section{International Editorial Board}

R.L. Alford, Houston, Tex.

M. Anniko, Uppsala

Y.A. Bayazit, Ankara

H.H. Birdsall, Houston, Tex.

P.J. Bradley, Nottingham

J. Califano, Baltimore, Md.

P.F. Castellanos, Bimingham, Ala.

C. Cernea, São Paulo

F.-L. Chi, Shanghai

A. Chiu, Tucson, Ariz.

N. Cohen, Philadelphia, Pa.

M.D. Eisen, Hartford, Conn.

L.M. Elden, Philadelphia, Pa.

E. Ferekidis, Athens

A. Ferlito, Udine

R.L. Ferris, Pittsburgh, Pa.

L.L. Gleich, Cincinnati, Ohio

D.-M. Han, Beijing

J.P. Harris, San Diego, Calif.

R. Häusler, Bern

I. Hochmair, Innsbruck

K. Hörmann, Mannheim

W. Hosemann, Greifswald
K.-B. Hüttenbrink, Köln

S. Iurato, Bari

A. Kakigi, Tokyo

B.N. Landis, Geneva

T. Linder, Luzern

S. Malekzadeh, Washington, D.C.

W.J. Mann, Mainz

J.B. Nadol, Jr., Boston, Mass.

J.N. Palmer, Philadelphia, Pa.

G.J. Petruzzelli, Chicago, Ill.

R. Probst, Zürich

A. Rinaldo, Udine

R.J. Ruben, Bronx, N.Y.

I. Salahuddin, Karachi

A. Schrott-Fischer, Innsbruck

A. Shiotani, Saitama

G.A. Tavartkiladze, Moscow

T.N. Teknos, Columbus, Ohio

K. Tomoda, Osaka

R.P. Tufano, Baltimore, Md.

R.T. Younis, Miami, Fla.

P. Zbären, Bern
Printed in Switzerland on acid-free and non-aging paper (ISO 9706) by Reinhardt Druck, Basel
Appears bimonthly: 1 volume per year (6 issues) 
Submission

Only original papers written in English should be submitted using the online submission website at:

www.karger.com/orl

Should you experience any problems with your submission, please contact the Editorial Office at:

\section{orl@karger.com}

Bert W. O’Malley, Jr. M.D.

S. Karger AG

Editorial Office ORL

PO Box

CH-4009 Basel (Switzerland)

Tel. +4161306 1360

Fax +41613061434

Suggested reviewers: Please list four complete mailing and e-mail addresses of potential reviewers for your manuscript. The names you suggest should not be ORL Editorial Board members; should not have been co-authors or co-workers over the past 3 years nor should they be persons working in the same institution as yourself or any of the co-authors.

\section{Conditions}

All manuscripts are subject to editorial review. Manuscripts are received with the explicit understanding that they are not under simultaneous consideration by any other publication. Submission of an article for publication implies the transfer of the copyright from the author to the publisher upon acceptance. Accepted papers become the permanent property of $O R L$ and may not be reproduced by any means, in whole or in part, without the written consent of the publisher. It is the author's responsibility to obtain permission to reproduce illustrations, tables, etc. from other publications.

\section{Conflicts of Interest}

Authors are required to disclose any sponsorship or funding arrangements relating to their research and all authors should disclose any possible conflicts of interest. Conflict of interest statements will be published at the end of the article.

Types of Papers

Editorial

Review

Original Paper

High Impact Report

Case Report

How I do it

Letter to the Editor

\section{High Impact Reports}

Authors may also submit contributions to the new section 'Hight Impact Reports'. Papers should focus on novel and exciting translational and clinical research, should comprise no more than four printed pages incl. 3 figures and 20 references and should be submitted explicitly for this section. An expedited publication time of 8 weeks after acceptance is intended.

Reviews are either invited, or may be submitted for consideration. Invited reviews, if accepted, are not subject to page charges. The recommended length is 6 printed pages (approx. 16 manuscript pages).

\section{Letter to the Editor}

Letters are only accepted if they directly concern articles previously published in this journal and clinical subjects related to the matters discussed. The editor reserves the right to submit copies of such letters to the authors of the articles concerned prior to publication in order to permit them to respond in the same issue of the journal. Letters should have a maximum of one printed page (350-420 words, up to 8 references).

\section{Case Report}

The publication space available for case reports is very limited. The journal only considers case reports with significant new insights, specific diagnostic methodology or with an extremely unusual and memorable course.

\section{Arrangement}

Title page: The first page of each paper should indicate the title, the authors' names, the institute where the work was conducted, and a short title for use as running head.

Full address: The exact postal address of the corresponding author complete with postal code must be given at the bottom of the title page. Please also supply phone and fax numbers, as well as e-mail address.

Key words: Please supply 3-10 key words in English that reflect the content of the paper.

Abstract: Each paper needs an abstract in English of not more than $\mathbf{2 0 0}$ words. The abstract is of utmost importance. It should contain the following information: purpose of the study, procedures, results, conclusions and message of the paper.

Footnotes: Avoid footnotes.

Tables and illustrations: Tables and illustrations (both numbered in Arabic numerals) should be stored in separate files. Tables require a heading and figures a legend, also in a separate file. When possible, group several illustrations in one block for reproduction ( $\max$. size $180 \times 223 \mathrm{~mm}$ ) or provide crop marks. $\mathrm{B} / \mathrm{w}$ half-tone and color illustrations must have a final resolution of $300 \mathrm{dpi}$ after scaling, line drawings one of $800-1,200 \mathrm{dpi}$.

Color illustrations

Online edition: Color illustrations are reproduced free of charge. In the print version, the illustrations are reproduced in black and white. Please avoid referring to the colors in the text and figure legends.

Print edition: Up to 6 color illustrations per page can be integrated within the text at CHF 800.- per page.

References: In the text identify references by Arabic numerals [in square brackets]. Material submitted for publication but not yet accepted should be noted as [unpublished data] and not be included in the reference list. The list of references should include only those publications which are cited in the text. Do not alphabetize; number references in the order in which they are first mentioned in the text. The surnames of the authors followed by initials should be given. There should be no punctuation other than a comma to separate the authors. Preferably, please cite all authors. Abbreviate journal names according to the Index Medicus system. Also see International Committee of Medical Journal Editors: Uniform requirements for manuscripts submitted to biomedical journals (www.icmje.org).

Examples

(a) Papers published in periodicals: Chatel J-M, Bernard $\mathrm{H}$, Orson FM: Isolation and characterization of two complete Ara h 2 isoforms cDNA. Int Arch Allergy Immunol 2003;131:14-18.

(b) Papers published only with DOI numbers:

Theoharides TC, Boucher W, Spear K: Serum interleukin-6 reflects disease severity and osteoporosis in mastocytosis patients. Int Arch Allergy Immunol DOI: $10.1159 / 000063858$.

(c) Monographs: Matthews DE, Farewell VT: Using and Understanding Medical Statistics, ed 3, revised. Basel, Karger, 1996.

(d) Edited books: DuBois RN: Cyclooxygenase-2 and colorectal cancer; in Dannenberg AJ, Dubois RN (eds): COX-2. Prog Exp Tum Res. Basel, Karger, 2003, vol 37, pp $124-137$.

Reference Management Software: Use of EndNote is recommended for easy management and formatting of citations and reference lists.

\section{Digital Object Identifier (DOI)}

S. Karger Publishers supports DOIs as unique identifier for articles. A DOI number will be printed on the title page of each article. DOIs can be useful in the future for identifying and citing articles published online without volume or issue information. More information can be found at www.doi.org.

\section{Author's Choice ${ }^{\mathrm{TM}}$}

Karger's Author's Choice ${ }^{\mathrm{TM}}$ service broadens the reach of your article and gives all users worldwide free and full access for reading, downloading and printing at www.karger.com. The option is available for a one-time fee of $\mathrm{CHF}$ 3,000 .-, which is a permissible cost in grant allocation. More information can be found at www.karger.com/authors_choice.

\section{Supplementary Material}

Supplementary material is restricted to additional data that are not necessary for the scientific integrity and conclusions of the paper. Please note that all supplementary files will undergo editorial review and should be submitted together with the original manuscript. The Editors reserve the right to limit the scope and length of the supplementary material. Supplementary material must meet production quality standards for Web publication without the need for any modification or editing. In general, supplementary files should not exceed $10 \mathrm{Mb}$ in size. All figures and tables should have titles and legends and all files should be supplied separately and named clearly. Acceptable files and formats are: Word or PDF files, Excel spreadsheets (only if the data cannot be converted properly to a PDF file), and video files (.mov, .avi, .mpeg).

\section{NIH-Funded Research}

The U.S. National Institutes of Health (NIH) mandates under the NIH Public Access Policy that final, peer-reviewed manuscripts appear in its digital database within 12 months of the official publication date. As a service to authors, Karger submits the final version of your article on your behalf to PubMed Central. For those selecting our premium Author's Choice ${ }^{\mathrm{TM}}$ service, we will send your article immediately upon publishing, accelerating the accessibility of your work without the usual embargo. More details on NIH's Public Access Policy is available at http://publicaccess.nih.gov/policy.htm

\section{Self-Archiving}

Karger permits authors to archive their pre-prints (i.e. prerefereeing) or post-prints (i.e. final draft post-refereeing) on their personal or institution's servers, provided the following conditions are met: Articles may not be used for commercial purposes, must be linked to the publisher's version, and must acknowledge the publisher's copyright. Authors selecting Karger's Author's Choice ${ }^{\mathrm{TM}}$ feature, how ever, are also permitted to archive the final, published version of their article, which includes copyediting and design improvements as well as citation links.

\section{Page Charges}

There are no page charges for papers of 4 or fewer printed pages (including tables, illustrations and references). Each additional complete or partial page is charged to the author at CHF 650.-. The allotted size of a paper is equal to approx. 10 manuscript pages (double-spaced, including tables, illustrations and references).

\section{Proofs}

Unless indicated otherwise, proofs are sent to the corresponding author and should be returned with the least possible delay. Alterations other than the correction of printer's errors are charged to the author.

\section{Reprints}

Order forms and a price list are sent with the proofs. Orders submitted after the issue is printed are subject to considerably higher prices.

\section{KARGER}

E-Mail karger@karger.com www.karger.com
(C) 2013 S. Karger AG, Basel 
ISSN Print Edition: 0301-1569 ISSN Online Edition: 1423-0275

Journal Homepage: www.karger.com/orl

Publication Data: $O R L$ is published 6 times a year. Volume 75 with 6 issues appears in 2013.

Copyright: () 2013 S. Karger AG, Basel (Switzerland). All rights reserved. No part of this publication may be translated into other languages, reproduced or utilized in any form or by any means, electronic or mechanical, including photocopying, recording, microcopying, or by any information storage and retrieval system, without permission in writing from the publisher or, in the case of photocopying, direct payment of a specified fee to the Copyright Clearance Center.

Disclaimer: The statements, opinions and data contained in this publication are solely those of the individual authors and contributors and not of the publisher and the editor(s). The appearance of advertisements in the journal is not a warranty, endorsement, or approval of the products or services advertised or of their effectiveness, quality or safety. The publisher and the editor(s) disclaim responsibility for any injury to persons or property resulting from any ideas, methods, instructions or products referred to in the content or advertisements.
Subscription Rates: Subscriptions run for a full calendar year. Prices are given per year. Personal subscription:

Print or Online

CHF 795.-

EUR 641.-

USD 787.00

Print+Online combined CHF 843.-

EUR 680.-

USD 835.00

postage and handling (added to print and print+online)

CHF 43.20 Europe, CHF 62.40 Overseas

EUR 33.60

USD 57.60

Institutional subscription

Print or Online

Print+Online combined

CHF 1590.

EUR 1282.-

CHF 1749 .

USD 1574.00

postage and handling (added to print and print+online)

CHF 54.- Europe, CHF 78.- Overseas

EUR 42.-

USD 72.00

Airmail surcharge: CHF 52.50 / USD 49.50

Discount subscription prices:

Gesellschaft Schweizerischer HNO-Ärzte.
Back Volumes and Single Issues: Information on availability and prices of single print issues and print or electronic back volumes can be obtained from Customer Service atservice@karger.com.

Bibliographic Indices: This journal is regularly listed in bibliographic services, including Current Contents ${ }^{\circledR}$ and PubMed/MEDLINE.

Photocopying: This journal has been registered with the Copyright Clearance Center (CCC), as indicated by the code appearing on the first page of each article. For readers in the US, this code signals consent for copying of articles for personal or internal use, or for the personal or internal use of specific clients, provided that the stated fee is paid per copy directly to

Copyright Clearance Center Inc.

222 Rosewood Drive

Danvers, MA 01923 (USA)

A copy of the first page of the article must accompany payment. Consent does not extend to copying for general distribution, for promotion, for creating new works, or for resale. In these cases, specific written permission must be obtained from the copyright owner,

S. Karger AG, P.O. Box

CH-4009 Basel (Switzerland).
Subscription Orders:

Orders can be placed at agencies, bookstores, directly with the Publisher

\section{S. Karger AG}

Medical and Scientific Publishers

Allschwilerstrasse 10

CH-4009 Basel

Switzerland

t: +41613061111

e: karger@karger.com

w: www.karger.com

(for courier services only:

Allschwilerstrasse 10

CH-4055 Basel) f: +41613061234

\begin{tabular}{|c|c|}
\hline $\begin{array}{l}\text { or further Karger offices } \\
\text { or representatives: }\end{array}$ & $\begin{array}{l}\text { USA } \\
\text { S. Karger Publishers, Inc. } \\
26 \text { West Avon Road }\end{array}$ \\
\hline Germany & P.O. Box 529 \\
\hline S. Karger GmbH & Unionville, CT 06085 \\
\hline Postfach & USA \\
\hline 79095 Freiburg & Toll free: +18008285479 \\
\hline Deutschland & $\mathrm{t}: \quad+18606757834$ \\
\hline (Hausadresse: Wilhelmstrasse 20A, & f: $\quad+18606757302$ \\
\hline $\begin{array}{l}\text { 79098 Freiburg) } \\
\mathrm{t}: \quad+49761452070\end{array}$ & e: karger@snet.net \\
\hline t: $\quad+497614520714$ & France \\
\hline e: information@karger.de & Librairie Médi-Sciences Sarl \\
\hline w: www.karger.de & $\begin{array}{l}\text { 36, bd de Latour-Maubourg } \\
\text { 75007 Paris }\end{array}$ \\
\hline Japan & France \\
\hline Karger Japan, Inc. & $\mathrm{t}: \quad+33(0) 145514258$ \\
\hline Shiba Daimon Asahi Bldg. 2F & $\mathrm{f:}+33(0) 145560780$ \\
\hline 1-2-23 Shiba Daimon & e: librairie@medi-sciences.fr \\
\hline Minato-ku & w: www.medi-sciences.fr \\
\hline Tokyo 105-0012 & \\
\hline Japan & \\
\hline t: +81364356242 & \\
\hline f: +81364356244 & \\
\hline e: publisher@karger.jp & \\
\hline w: www.karge & \\
\hline
\end{tabular}

Change of Address:

Both old and new address should be sent

to the subscription source.

\section{KARGER}

E-Mail karger@karger.com www.karger.com
(C) 2013 S. Karger AG, Basel

The Journal Home Page is available at: www.karger.com/orl
South East Asia, China and Taiwan Karger Regional Office (Malaysia)

CEO Suite Kuala Lumpur

Quill 7, 27th Floor

Jalan Stesen Sentral 5

KL Sentral

Kuala Lumpur 50470

Malaysia

t: +60327766803

f: +60327766999

e: service@karger.cn; r.chew@karger.cn

Karger China

10th Floor, Twin Towers (East)

B12 Jianguomenwai Avenue

Beijing 100022

China

$\mathrm{t}:+861051235033$

f: +861051235122

e: service@karger.cn; r.chew@karger.cn

w: www.karger.cn

India, Bangladesh, Sri Lanka

Medscience India

Plot No. 17, Yusuf Sarai Market

B.L. Glass Building, 2nd Floor

Sri Aurobindo Marg

New Delhi 110016

India

t: +911146029633

f: +911146029634

c: +919891052128

e: medsci.india@gmail.com 


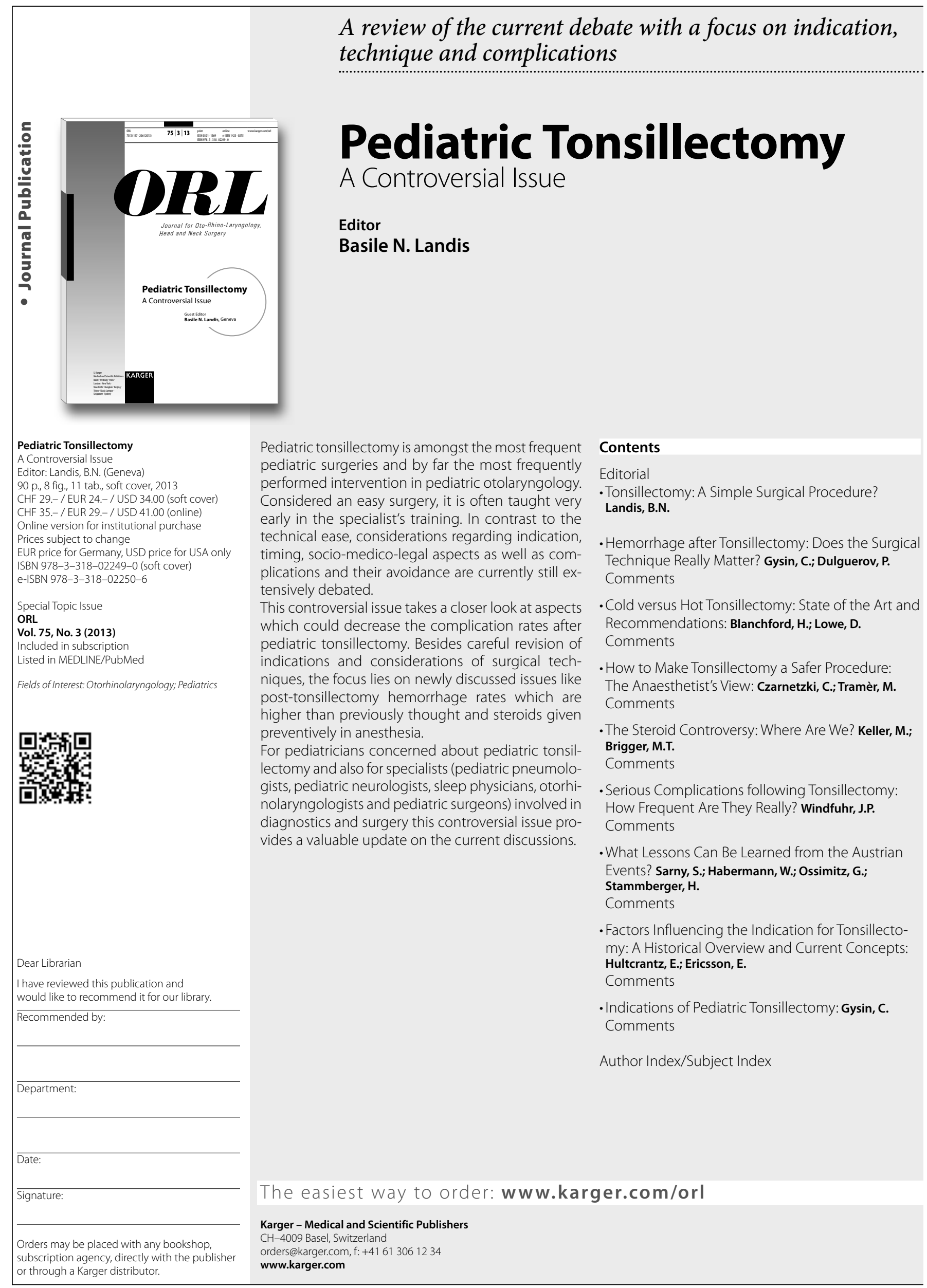




\section{Contents}

See the journal website for contents

KARGER Basel $\bullet$ Freiburg $\cdot$ Paris $\bullet$ London $\bullet$ New York $\cdot$ New Delhi $•$ Bangkok Beijing $\cdot$ Tokyo $\cdot$ Kuala Lumpur $\cdot$ Singapore $\bullet$ Sydney 


\title{
Nanomedicine - Basic and Clinical Applications in Diagnostics and Therapy
}

\author{
Editor \\ Christoph Alexiou
}

Nanomedicine - the application of nanotechnology to human health - is a promising field of research at the interface of physical, chemical, biological, and medical science. Recent advances have made it possible to analyze biological systems at cellular and subcellular levels, offering numerous promising approaches to improve medical diagnosis and therapy. It is expected that nanomedicine will have a great impact especially on drug delivery and imaging. In this context, the development of targeted, highly specific nanoparticles is of pivotal importance. The results of these advances will offer personalized diagnostic tools and treatments in the future.

Based on the 2nd Else Kröner-Fresenius-Symposium, this book presents a broad spectrum of topics ranging from nanoscale drug delivery/drug design to nanotoxicity and from diagnostics and imaging to therapeutic applications including antibody therapies. The contributions are authored by leading experts in the field and provide an excellent overview of the current knowledge in nanomedicine. Due to the interdisciplinary nature of the subject area this volume will be of special interest to physicians, biologists, chemists, engineers, and physicists as well as to students in the respective fields.

\section{KARGER}

\section{Contents}

Preface: Pahernik, $\boldsymbol{s}$.

Introduction: Alexiou, C.

Speakers at the Symposium

Nanoscale Drug Delivery/Drug Design

Nanocarriers for the Delivery of Drugs, Genes, and Diagnostics: Torchilin, V.P.

Synthesis of Magnetic Nanoparticles and Magnetic Fluids for Biomedical Applications: Vékás, L.; Tombácz, E.; Turcu, R.; Morjan, l.; Avdeev, M.V.; Krasia-Christoforou, T.; Socoliuc, V. Nanotechnology-Based Spatiotemporal Controlled Drug Delivery Strategies: Biswas, S.; Kumar, C.S.S.R.

Nanotoxicity

Preclinical Efficacy and Toxicity Testing of Engineered Nanomaterials: Grossman, J.H.; McNeil, S.E.

Interactions of Carbon Nanotubes with the Immune System: Focus on Mechanisms of Internalization and Biodegradation: Fadeel, B.; Shvedova, A.A.; Kagan, V.E.

Diagnostics and Imaging

Magnetic Particle Imaging: Principles and Clinical Application: Buzug, T.M.; Sattel, T.F.; Erbe, M.; Biederer, S.; Finas, D.; Diedrich, K.; Vogt, $F_{\text {; }}$ Barkhausen, J.; Borgert, J.; Lüdtke-Buzug, $K$.; Knopp, $T$.

www.karger.com/ekfsy
Nanoparticles in Clinical Trials: Hedgire, S.; McDermott, S.; Harisinghani, $M$.

Medical Applications of Plasmonic Nanoparticles: Alvarez-Puebla, R.A.; Liz-Marzán, L.M.

Pancreatic Cancer Stem Cells as New Targets for Diagnostics and Therapy: Clausell-Tormos, J.; Heeschen, $\mathrm{C}$.

Therapeutic Applications

Nanomedicine Approaches for Cancer Stem Cell Targeting and Personalized Cancer Treatment: Block, I.; Schmidt, S.; Lund Hansen, P.; Riedel, A.; Christiansen, $H$.; Mollenhauer, J.

Targeted Iron Oxide Nanocomplex as a Theranostic Agent for Cancer: Chang, E.H. Local Cancer Therapy with Magnetic

Nanoparticles: Tietze, R.; Lyer, S.; Schreiber, E.; Mann, J.; Dürr, S.; Alexiou, C.

Parameters Influencing the Efficacy of Magnetic Heating of Small Breast Tumors: Hilger, I.; Kaiser, W.A.

Antibody Therapies

Galectins, Glycans, and Mucins as Targets for Novel and Specific Antibody Therapies in Gynecologic Cancer Therapies: Jeschke, U.; Wiest, I.R.M.; Schindlbeck, C.; Dian, D.; Friese, K. The Commercial Development of Antibodies as Drugs: Eaton, M.A.W.; Adair, J.R.

Author Index / Subject Index

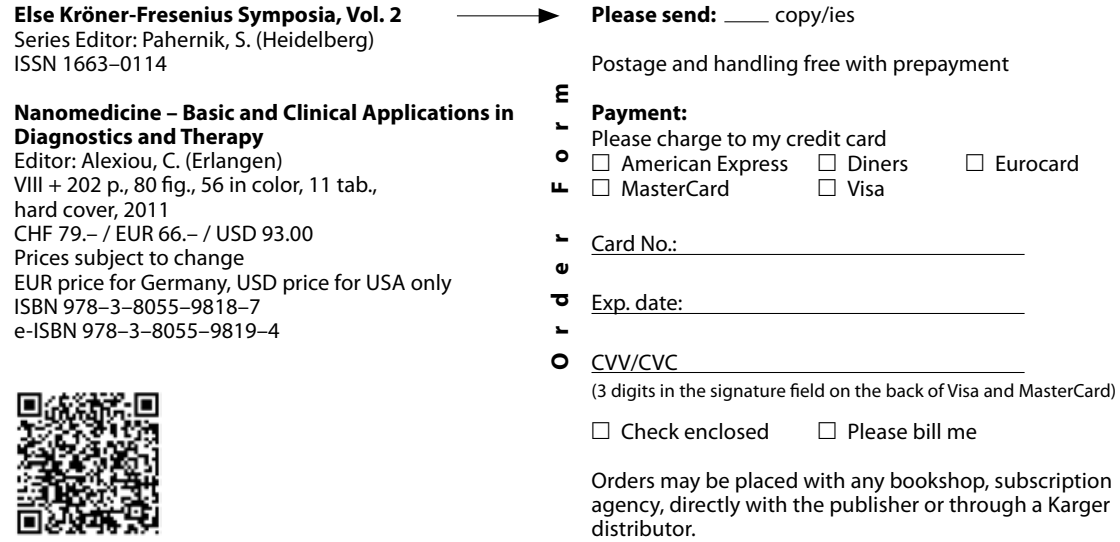

Please send: __ copy/ies

Postage and handling free with prepayment

E

Nanomedicine - Basic and Clinical Applications in Diagnostics and Therapy

Editor: Alexiou, C. (Erlangen)

VIII + 202 p., 80 fig., 56 in color, 11 tab.,

hard cover, 2011

CHF 79.- / EUR 66.- / USD 93.00

Prices subject to change

EUR price for Germany, USD price for USA only

ISBN 978-3-8055-9818-7

e-ISBN 978-3-8055-9819-4

\&

- Please charge to my credit card

- $\square$ American Express $\square$ Diners

ᄂ $\square$ Master

$\square$ Visa

Card No

๑

- Exp date:

CVV/CVC

( 3 digits in the signature field on the back of Visa and MasterCard)

$\square$ Check enclosed $\quad \square$ Please bill me

Orders may be placed with any bookshop, subscription agency, directly with the publisher or through a Karger distributor.

Fax: +41613061234

S. Karger AG, P.O. Box, CH-4009 Basel (Switzerland)

E-Mail orders@karger.ch,www.karger.com

Name/Address: 


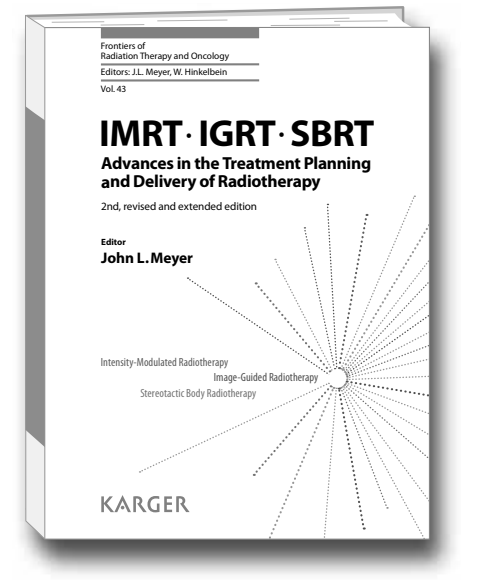

Contents

Preface: Meyer, J.L.

$\underline{\text { Introduction }}$

General Concepts and Methods

Economic Perspectives

\section{IMRT and IGRT: Intensity-Modulated and} Image-Guided Radiotherapy

IMRT: Advances in Treatment Design and Delivery Clinical Implementation of Intensity-Modulated Arc Therapy: Shepard, D.M.; Cao, D

IGRT: Advances in Targeting Therapy

4D Imaging and 4D Radiation Therapy: A New Era of Therapy Design and Delivery: Low, $\boldsymbol{D}$.

Locating and Targeting Moving Tumors with Radiation Beams: Keall, $\boldsymbol{P}$.

Integrating IMRT and IGRT into Treatment Delivery Technologies of Image Guidance and the Development of Advanced Linear Accelerator Systems for Radiotherapy: Wu, V.W.C. et al.

Helical Tomotherapy: Image-Guided and Adaptive Radiotherapy: Kupelian, $P_{\text {; }}$ Langen, $\boldsymbol{K}$.

The CyberKnife in Clinical Use: Current Roles,

Future Expectations: Dieterich, S.; Gibbs, I.C.

www.karger.com/frato

\section{IMRT, IGRT, SBRT - Advances in the Treatment Planning and Delivery of Radiotherapy}

\section{2nd, revised and extended edition}

Editor

John L. Meyer
IMRT and IGRT Clinical Treatment Programs

Image Guidance and the New Practice of Radiotherapy: What to Know and Use from a Decade of Investigation: Kim, J. et al.

Head and Neck Cancers

Intensity-Modulated and Image-Guided Radiation Therapy for Head and Neck Cancers: Chu, K.P.-M.; Le, Q.-T.

Delineating Neck Targets for Intensity-Modulated Radiation Therapy of Head and Neck Cancer: David, M.B.; Eisbruch, $A$.

Thoracic Cancers

Motion Management and Image Guidance for Thoracic Tumor Radiotherapy: Clinical Treatment Programs: Loo, B.W., Jr. et al.

Breast Cancer

Intensity-Modulated Radiotherapy for Breast Cancer: Advances in Whole and Partial Breast Treatment: White, J.R.; Meyer, J.L.

Abdominal Cancers

Image-Guided Radiotherapy Strategies in Upper Gastrointestinal Malignancies: Swaminath, A.; Dawson, L.A.

Lymphomas

Radiotherapy Planning for the Lymphomas: Expanding Roles for Biologic Imaging: Hoppe, $\boldsymbol{R}$. Prostate Cancer

Image-Guided, Adaptive Radiotherapy of Prostate Cancer: Toward New Standards of Radiotherapy Practice: Kupelian, P.; Meyer, J.L.

\section{SBRT: Stereotactic Body Radiotherapy}

SBRT Advances

The Expanding Roles of Stereotactic Body Radiation Therapy and Oligofractionation: Toward a New Practice of Radiotherapy: Kavanagh, B.D. et al.

Stereotactic Body Radiation Therapy: Normal Tissue and Tumor Control Effects with Large Dose per Fraction: Timmerman, $\boldsymbol{R}$. et al.

Thoracic Cancers

Stereotactic Body Radiation Therapy for Thoracic Cancers: Recommendations for Patient Selection, Setup and Therapy: Timmerman, $R$. et al.

Gastrointestinal Cancers

Stereotactic Body Radiation Therapy for Gastrointestinal Malignancies: Minn, A.Y. et al.

Genitourinary Cancers

Stereotactic Body Radiotherapy for Prostate Cancer: Current Results of a Phase II Trial: King, C.

\section{Proton Beam Radiotherapy}

Techniques and Technologies

Proton Therapy: Clinical Gains through Current and Future Treatment Programs: Mohan, R.; Bortfeld, $T$.

Medical Applications and Advances

Proton Therapy in the Clinic: DeLaney, T.F.

\section{KARGER}

Please send:

copy/ies

Frontiers of Radiation Therapy and Oncology, Vol. 43

Series Editors: Meyer, J.L. (San Francisco, Calif.) Hinkelbein, W. (Berlin)

ISSN 0071-9676 / e-ISSN 1662-3789

IMRT, IGRT, SBRT - Advances in the Treatment Planning and Delivery of Radiotherapy

2nd, revised and extended edition

Editor: Meyer, J.L. (San Francisco, Calif.)

$\mathrm{X}+496$ p., 211 fig., 175 in color, 41 tab., online

supplementary material, hard cover, 2011

CHF 198.- / EUR 146.50 / USD 198.00

Prices subject to change

EUR price for Germany, USD price for USA only ISBN 978-3-8055-9680-0 e-ISBN 978-3-8055-9681-7
Postage and handling free with prepayment

E

- Payment:

Please charge to my credit card

- $\square$ American Express $\square$ Diners $\square$ Eurocard

ᄂ $\square$ MasterCard $\square$ Visa

- Card No.

ข

ర Exp. date

2

- CVV/CVC

( 3 digits in the signature field on the back of Visa and MasterCard)

$\square$ Check enclosed $\quad \square$ Please bill me

Orders may be placed with any bookshop, subscription agency, directly with the publisher or through a Karger distributor.
Fax: +41 613061234

S. Karger AG, P.O. Box, CH-4009 Basel (Switzerland) E-Mail orders@karger.ch, www.karger.com

Name/Address: 


\section{An international journal of communication sciences and disorders}

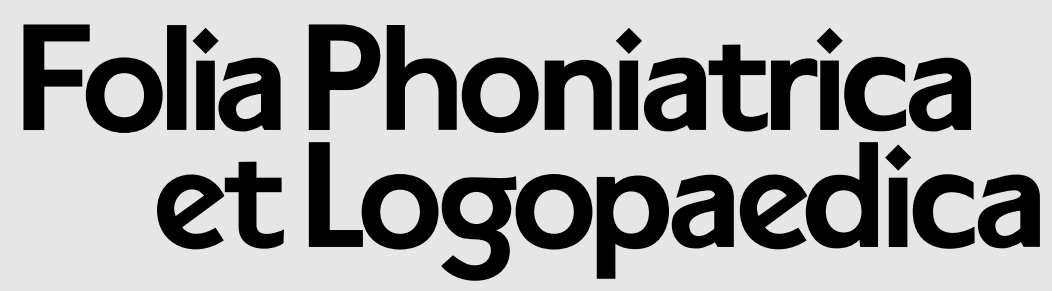

International Journal of Phoniatrics, Speech Therapy and Communication Pathology

Editor-in-Chief

G.Weismer, Madison Wisc.

More information at

\section{www.karger.com/fpl}

- Pay-per-View and Subscriber Access to Full Text

- Full Table of Contents

- Full Editorial Board

- Free Abstracts and Selected Articles

- Online Sample Issue

- Submission/Guidelines for Authors

- Subscription Details

- Free Alert Service

- Online Library Recommendation

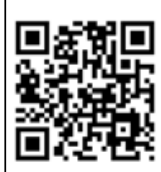

Folia Phoniatrica et Logopaedica

2014: Volume 66

6 issues per volume

Languages: English, German, French

ISSN 1021-7762 (print)

ISSN 1421-9972 (online)
Associate Editors

D.-E. Bamiou, London

H.G. Bosshardt, Bochum

T. Klee, Christchurch

M. McAuliffe, Christchurch

P. Paquier, Bruxelles

R. Shrivastav,

East Lansing, Mich.
Impact Factor: 1.077

\section{FoliaPhoniatrica et Logopaedica}

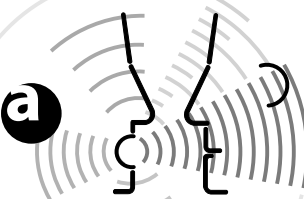

Association of

Logopedics and Phoniatrics (ILLP)



a

\section{Selected contributions}

- The Effects of Aging on Acoustic Parameters of Voice: Dehqan, A. (Zahedan); Scherer, R.C. (Bowling Green, Ohio); Dashti, G.; Ansari-Moghaddam, A.; Fanaie S. (Zahedan)

- Design and Evaluation of an Electrolarynx with Tonal Control Function for

Mandarin: Wan C.; Wang E.; Wu L.; Wang S.; Wan M. (Xi'an)

- Voice Risk Factors in Kindergarten Teachers in Greece: Helidoni, M. (Heraklion);

Murry, T. (New York, N.Y.); Chlouverakis, G. (Heraklion); Okalidou, A. (Salonika);

Velegrakis, G. (Heraklion)

- Cross-Cultural Adaption and Translation of the Voice Handicap Index into

Norwegian: Karlsen, T.; Grieg, A.R.H.; Heimdal, J.-H.; Aarstad, H.J. (Bergen)

- Pitch Control in Esophageal and Tracheoesophageal Speech of Cantonese:

Yan, N. (Nanjing/Hong Kong); Lam, P.K.Y.; Ng, M.L. (Hong Kong)

- Current Clinical Practices in Aphasia Therapy in Finland: Challenges in Moving

towards National Best Practice: Klippi, A.; Sellman, J.; Heikkinen, P.; Laine, M.

(Helsinki)

- Quality of Life after Stroke: Evaluation of the Greek SAQOL-39g: Efstratiadou, E.A.;

Chelas, E.N.; Ignatiou, M.; Christaki, V.; Papathanasiou, I.; Hilari, K. (London)

- Communicative Clusters after a Right-Hemisphere Stroke: Are There Universal

Clinical Profiles? Ferré, P. (Montréal, Qué.); Fonseca, R.P. (Montréal, Qué./Porto Alegre);

Ska, B.; Joanette, Y. (Montréa, Qué.)
Published since 1947, Folia Phoniatrica et Logopaedica provides a forum for international research on the anatomy, physiology, and pathology of structures of the speech, language, and hearing mechanisms. Original papers published in this journal report new findings on basic function, assessment, management, and test development in communication sciences and disorders, as well as experiments designed to test specific theories of speech, language, and hearing function. Review papers of high quality are also welcomed. 


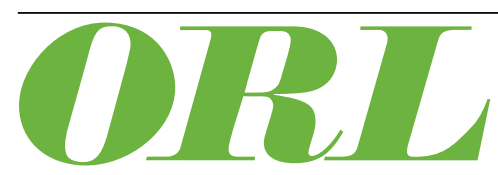

Original Papers

207 Does Smoking Influence the Surgical Outcome of a Myringoplasty? Migirov, L.; Lipschitz, N.; Wolf, M. (Tel Hashomer)

211 Effectiveness of the Combined Hearing and Masking Devices on the Severity and Perception of Tinnitus: A Randomized, Controlled, Double-Blind Study

Oz, I.; Arslan, F.; Hizal, E.; Erbek, S.H.; Eryaman, E.; Senkal, O.A.; Ogurlu, T.; Kizildag, A.E.; Ozluoglu, L.N. (Ankara)

221 Expression of Tumor Necrosis Factor-Like Weak Inducer of Apoptosis in Human Middle Ear Cholesteatoma

Park, M.; Lee, B.; Lee, J. (Bucheon)

228 Superior Mediastinal Dissection for Papillary Thyroid Carcinoma: Approaches and Outcomes

Liu, J.; Wang, X.; Liu, S.; Liu, X.; Tang, P.; Xu, Z. (Beijing)

245 Clinical Analysis of Recurrent Sudden Sensorineural Hearing Loss

Park, I.-S.; Kim, Y.B.; Choi, S.H.; Hong, S.M. (Hwaseong)

Case Report

240 Surgical Management of Parapharyngeal Ganglioneuroma: Case Report and Review of the Literature

Albuquerque, B.S.; Farias, T.P.; Dias, F.L.; Torman, D. (Rio de Janeiro)

How I Do It

250 Preauricular Transmandibular and Transzygomatic Approach for Tumors of the Infratemporal Fossa Revisited

Timoshenko, A.P.; Asanau, A.; Gavid, M.; Colin, V.; Martin, C.; Prades, J.-M. (Saint-Etienne) 